American Journal of Applied Sciences 8 (5): 452-458, 2011

ISSN 1546-9239

(C) 2010 Science Publications

\title{
Modeling Fire Evacuation of a Library Building based on the Numerical Simulation
}

\author{
Withayavuth Jirasingha and Supat Patvichaichod \\ Department of Mechanical Engineering, Kasetsart University, Si Racha Campus, \\ 199, Sukhumvit road, Chonburi, 20230, Thailand
}

\begin{abstract}
Problem statement: This study investigates the fire evacuation problem of the library building by using the Fire Dynamics Simulator with Evacuation (FDS+Evac.) programming. Approach: The assumption is made that the sprinkler system is installed in the building but the system is malfunction, which is considered as the worst case of the situation. The simulations are divided into 4 cases, which are case 1; the numbers of evacuating persons are 517 persons and the heat release rate is $5 \mathrm{MW}$, case 2; the numbers of evacuating persons are 517 persons and the heat release rate is $7 \mathrm{MW}$, case 3; the numbers of evacuating persons are 788 persons and the heat release rate is $5 \mathrm{MW}$ and case 4; the numbers of evacuating persons are 788 persons and the heat release rate is $7 \mathrm{MW}$. Results: The results are shown that the 1st case and the 2nd case have the evacuation times of 8.63 and $8.81 \mathrm{~min}$, respectively. There is no dead person found from both cases. For the 3rd and the last case, the evacuation times are 18.17 and 18.83 min, respectively. The 3 rd case has 1 dead person and the last case has 18 dead persons, respectively. Conclusion: The number of evacuating person and a size of fire have a directly impact on the evacuating person. The reasons are the crowded situation of evacuation and a higher toxicity that is occurred. So, the stairway of the building has to be improved and changed to be the fire escape. This brings to the increasing in the capability of the evacuation.
\end{abstract}

Key words: Fire evacuation, numerical simulation, library building, Fire Dynamics Simulation (FDS), evacuation time, Fraction Effective Dose (FED), Air Handling Units (AHU)

\section{INTRODUCTION}

The fire evacuation is a necessary activity required in various emergency situations for examples, the fire occurrence, the earthquake, a gas leak, the hostage situation and the bombing. The evacuation time depends on various components, which are the user characteristics, the building characteristics and the building layout. Although the building layout is well designed, the testing, the efficiency measurement and the capacity of means of egress have to be often implemented. Merchant (1982) mentioned about the 3 parts of escape time (Tescape) components as shown in Eq. 1.

Tescape $=\mathrm{Tp}+\mathrm{Ta}+\mathrm{Tt}$

Where:

$\mathrm{Tp}=$ A perception time of fire occurrence

$\mathrm{Ta}=$ An action time of fire occurrence

$\mathrm{Tt}=\mathrm{A}$ travel time to a safe place
The simulation program of evacuation in this research is Fire Dynamics Simulator with Evacuation (FDS+Evac) that is able to calculate only for the evacuation time but the program has not got a function to calculate the perception time and the action time. However, the program is able to assign the initial time of evacuation or the response time in which the evacuating person can perceive the fire occurrence and react to the evacuation time. In addition, there are other important factors influencing on the travel time, which are a population size, the evacuation speed, the congestion of the people, the door width, the evacuation route, the distance to the safe place, the building shape and dimension, behavior and familiarity to the place and the increment of toxicity in combustion process emerged from the decoration material in the building. Using the simulation program of evacuation is a choice to determine the potential or the fault of evacuation area. The time and cost will be saved in case of the evacuation plan is prepared in advance. The building modification is required by the evacuation plan. A lot of researchers contributed to the evacuation and numerical

Corresponding Author: Supat Patvichaichod, Department of Mechanical Engineering, Kasetsart University, Si Racha Campus, 199, Sukhumvit road, Chonburi, 20230, Thailand 
simulation such as, Ma and Quintiere (2003) and Xin et al. (2005). Zhang et al. (2007); Lin and Chuah (2008); Roh et al. (2009); Qin et al. (2009); Mouilleau and Champassith (2009); Kwaire et al. (2009); Merry et al. (2009); Zahim et al. (2009); Momani (2010) and Majee and Roy (2010).

\section{MATERIALS AND METHODS}

Building fire modeling: The library building under studied size is $22.8 \mathrm{~m}(\mathrm{~W}) \times 59.58 \mathrm{~m}(\mathrm{~L}) \times 15.8 \mathrm{~m}(\mathrm{H})$ having 4 stories and the left stair is a fire stair but the right stair is normal stair, as shown in Fig. 1.

From the NFPA 101, Life Safety Code (2009), the category of library is classified by the types of the assembly building. In case of the users are more than 50 persons, the simulation models then are divided into 2 cases. The first case is referred by the real data of maximum number of user (517 persons) and the second case is referred and calculated from the NFPA 101, Life Safety Code (2009) (788 persons).

Walter and Wan (2005) mentioned the heat release rate of models used in Asia as shown in Table 1 in which the polyurethane is used in their research. There are 2 cases of the modeling. The first case has 5,000 $\mathrm{kW}$ of thermal energy and $5 \mathrm{~m}^{2}$ of sectional area. And the second case has 7,000 $\mathrm{kW}$ of thermal energy and 7 $\mathrm{m}^{2}$ of sectional area. Both cases have the $1,000 \mathrm{~kW} \mathrm{~m}^{-2}$ of heat release rate per area. Assume that the fire source occur at air handling units of the 3rd floor as shown in Fig. 2.

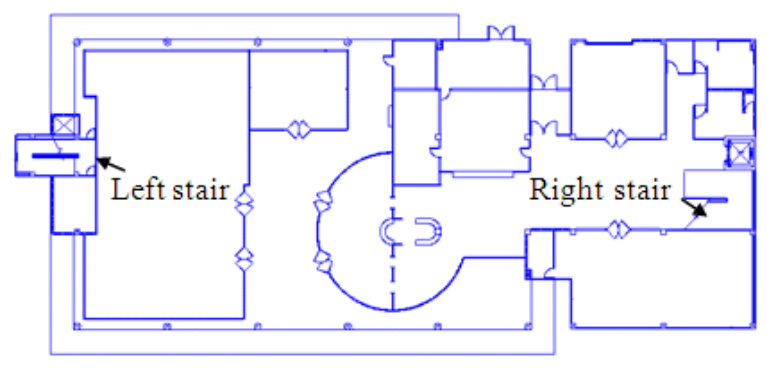

Fig. 1: Depicts the top view of library building

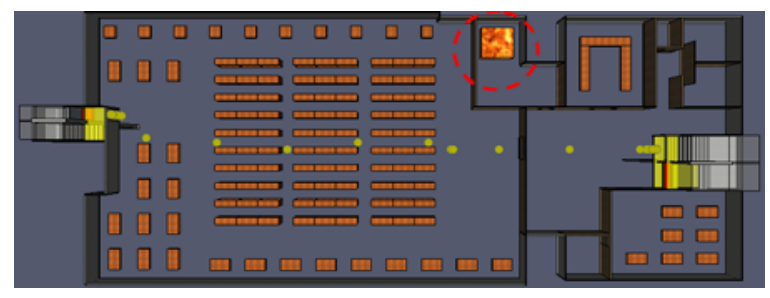

Fig. 2: The source of a fire at the 3 rd floor
CFD numerical modeling: This study used Fire Dynamics Simulation (FDS) for the tunnel smoke flow simulation. FDS is a fluid dynamics program developed by National Institute of Standards and Technology (NIST Special Publication 1018-5, 2010; NIST Special Publication 1019-5, 2010). FDS is targeted for low Mach number heat and flow field analysis. The computer program can be used to analyze fire related problems, such as temperature, velocity and concentration distribution. Hu et al. (2006) used FDS to study the maximum smoke temperature under the tunnel ceiling. Predicted FDS results for near fire field agreed fairly well with the experiments. FDS solves flow equations numerically. The physical equations include Navier-Stokes equations for flow analysis, energy conservation equations for temperature distribution and other scalar equations for smoke and particulates transport. Governing equations are described as follows.

Conservation of mass:

$\frac{\partial \rho}{\partial t}+\nabla \cdot(\rho u)=0$

Conservation of momentum:

$\rho\left(\frac{\partial \mathrm{u}}{\partial \mathrm{t}}+(\mathrm{u} \cdot \nabla) \mathrm{u}\right)+\nabla \rho=\rho \mathrm{g}+\mathrm{f}+\nabla \cdot \tau$

Conservation of energy:

$$
\begin{aligned}
\frac{\partial}{\partial \mathrm{t}}(\rho \mathrm{h})+\nabla \cdot \rho \mathrm{hu}-\frac{\mathrm{Dp}}{\mathrm{Dt}} & =\dot{\mathrm{q}} \mathrm{\prime \prime}-\nabla \cdot \mathrm{q}_{\mathrm{r}}+\nabla \cdot \mathrm{k} \nabla \mathrm{T} \\
& +\nabla \cdot \sum_{1} \mathrm{~h}_{1}(\rho \mathrm{D})_{1} \nabla \mathrm{Y}_{1}
\end{aligned}
$$

Conservation of species:

$\frac{\partial}{\partial t}\left(\rho Y_{1}\right)+\nabla \cdot \rho Y_{1} u=\nabla \cdot(\rho D)_{1} \nabla Y_{1}+\dot{W}_{1}^{\prime \prime}$

The results from a numerical analysis are sensitive to the grid size used. The proper grid size is discussed later as related to the parameters such as the fire size and the properties of air. Grid resolution is required to compare with the fire characteristic diameter. Grid independent test has to be conducted for the grid size selection. This grid analysis is required to obtain viable computer simulation results. Specifically, grid size determination is important for field near the larger gradient location such as near the fire site.

Table 1: Heat release rate

\begin{tabular}{ll}
\hline Types of buildings & HRR $(\mathrm{kW})$ \\
\hline Airport and rail station & $>7,000$ \\
Department store and public building & 5,000 \\
Hall in the building or open area in building & $>7,000$ \\
Barrier in rail station & 1,000 \\
\hline
\end{tabular}




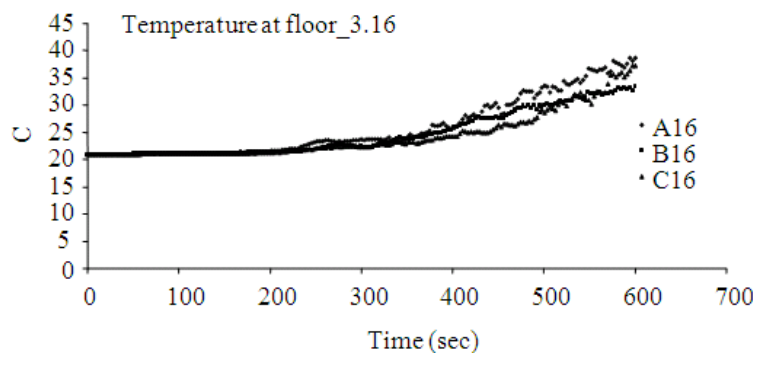

Fig. 3: Depicts the temperature values for monitoring equipment no. 16 of the 3 rd floor

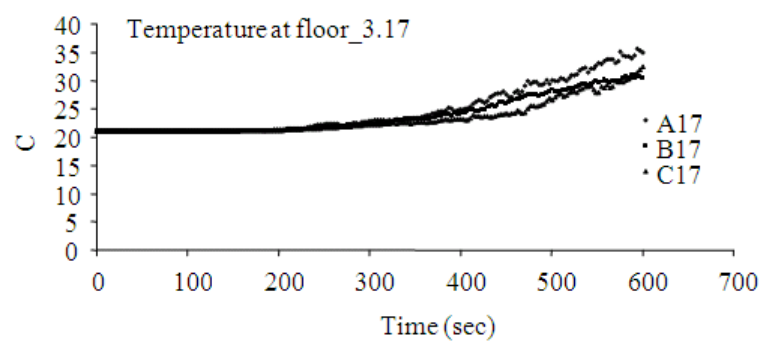

Fig. 4: Depicts the temperature values for monitoring equipment no. 17 of the 3 rd floor

Table 2: Grid resolution analysis

\begin{tabular}{|c|c|c|c|c|c|c|c|}
\hline \multirow[b]{2}{*}{ Resolution } & \multicolumn{3}{|c|}{ Number of grid } & \multicolumn{3}{|c|}{ Grid size } & \multirow{2}{*}{$\begin{array}{l}\mathrm{CPU} \\
\text { time }(\mathrm{h})\end{array}$} \\
\hline & NPX & NPY & NPZ & $\Delta \mathrm{X}$ & $\Delta \mathrm{Y}$ & $\mathrm{VZ}$ & \\
\hline Coar & 120 & 46 & 35 & 0.50 & 0.50 & 0.50 & 2.73 \\
\hline Moderate & 160 & 62 & 41 & 0.375 & 0.375 & 0.375 & 7.62 \\
\hline Fine & 240 & 92 & 62 & 0.250 & 0.250 & 0.250 & 36.75 \\
\hline
\end{tabular}

Grid resolution analysis: To determine the suitable grid size in the model, the experiment is conducted by reducing the grid size. The change of the equipment is then examined to select the grid size by the desired resolution for using the model. Table 2 shows the CPU time to calculate the grid size by sizes of the fire model.

From Fig. 3 and 4, the temperatures of 3 grid sizes are presented. The highest values of the temperatures belong to the coarse grid size, which is represented by " $\mathrm{A}$ ". The center line and the bottom line show the moderate ("B") and fine grid size ("C"), respectively. The monitoring equipment is installed in front of the source of a fire. The differentiation between the coarse and moderate grid size or $0.5=>0.375$ is more than the differentiation between the moderate and fine grid size or $0.375=>0.25$. Then, the differentiation of grid size with 0.375 and 0.25 has a small change in a graph and does not have a significant effect on the result. In addition, the grid size of 0.375 uses the run time faster than the grid size of 0.25 . The grid size of 0.375 is then selected to be run in the next 4 cases:
Case 1: The real maximum number of the evacuating person is 517 persons and a size of fire is 5 MW.

Case 2: The real maximum number of evacuating person is 517 persons and a size of fire is 7 MW.

Case 3: The number of evacuating person calculated by the NFPA 101, Life Safety Code (2009) is 788 persons and a size of fire is $5 \mathrm{MW}$.

Case 4: The number of evacuating person calculated by the NFPA 101, Life Safety Code (2009) is 788 persons and a size of fire is $7 \mathrm{MW}$.

The combustion product analysis: The product from the combustion is the toxic quantity that can be a cause of death to the evacuating person. In this research, only gases that make the evacuating person unconscious are investigated. Whereas the density ratio of Purser (1995) or the Fraction Effective Dose (FED) is shown in Eq. 6:

$\mathrm{FED}_{\text {tot }}=\mathrm{FED}_{\mathrm{CO}_{2}} \times \mathrm{HV}_{\mathrm{CO}_{2}}+\mathrm{FED}_{\mathrm{O}_{2}}$

In addition, the ratio of $\mathrm{CO}$ that is harmful or can decrease the ability is shown in Eq. 7:

$\mathrm{FED}_{\mathrm{CO}}=4.607 \times 10^{-7}\left(\mathrm{C}_{\mathrm{CO}}\right)^{1.036} \times \mathrm{t}$

where, $\mathrm{C}_{\mathrm{CO}}$ is the percentage of density by volume of CO.

The ratio of $\mathrm{O}_{2}$ that is harmful and is a cause of hypoxemia is shown in Eq. 8:

$\mathrm{FED}_{\mathrm{O}_{2}}=\frac{\mathrm{t}}{60 \exp \left[8.13-0.54\left(20.9-\mathrm{C}_{\mathrm{O}_{2}}\right)\right]}$

where, $\mathrm{C}_{\mathrm{O}_{2}}$ is the percentage of density by volume of $\mathrm{O}_{2}$.

The factor of $\mathrm{CO}_{2}$ that is a cause of suffocation is further shown in Eq. 9:

$\mathrm{HV}_{\mathrm{CO}_{2}}=\frac{\exp \left(0.1930 \mathrm{C}_{\mathrm{CO}_{2}}+2.004\right)}{7.1}$

where, $\mathrm{C}_{\mathrm{CO} 2}$ is the percentage of density by volume of $\mathrm{CO}_{2}$.

Table 3 and Table 4 show values of resistable temperature of human and $\mathrm{CO}$ quantity in periods. These values are followed by the NFPA 130, Standard for Fixed Guideway Transit and Passenger Rail Systems, 2000 Edition (National Fire Protection Association, 2000). 
Am. J. Applied Sci., 8 (5): 452-458, 2011

\section{RESULTS}

In Table 5, the results of 4 cases of evacuating person are shown by various number of evacuating person and sizes of fire.

In Table 6-9, the average temperatures of 4 floors of the case study building are concluded, whereas Fig. 5-16 depicts the smoke movement inside the library building of case 4 . The source of a fire starts at the Air Handling Units (AHU) of the 3rd floor. The smoke moves from the source room to the 4th floor and passes to the right stairway. Some smoke moves to the book store of the 3rd floor. The smoke moving at the 4th floor is faster than the 3rd floor because the 4th floor is the open air area. The smoke moves to the fire stair on the left hand side of the building and then moves out form the fire stair at the 3rd floor, the 2nd floor and the 1st floor. The smoke moving from the right stairway of the 3rd floor expands to the 2 nd and the 1st floor. After that the smoke moves to the front of the building at the main entrance. The smoke suffocation is occurred from both of front and back sides of the building. Except for the case 1 and the case 2 , the smoke does not move to the 1 st floor immediately because the simulation time is rather short.

Table 10 and 11 show the $\mathrm{O}_{2}$ and $\mathrm{CO}$ quantity of the 3 rd floor, which is the source of a fire.

Table 3: Shows the resistable periods of human by various temperatures

\begin{tabular}{ll}
\hline Temperature & Resistable period \\
\hline $140^{\circ} \mathrm{F}\left(60^{\circ} \mathrm{C}\right)$ & $2-3 \mathrm{sec}$ \\
$120^{\circ} \mathrm{F}\left(49^{\circ} \mathrm{C}\right)$ & Less than $6 \mathrm{~min}$ \\
\hline
\end{tabular}

Table 4: Shows the resistable periods of human by various CO quantities

\begin{tabular}{ll}
\hline CO & Resistable period \\
\hline$\geq 2,000$ PPM & $2-3 \mathrm{sec}$ \\
1,500 PPM & Less than 6 min \\
800 PPM & Less than 15 min \\
50 PPM & Residue from the burning \\
\hline
\end{tabular}

Table 5: Presents the total time of evacuation from the library building

\begin{tabular}{lllll}
\hline & $\begin{array}{l}\text { Number of } \\
\text { Case no. }\end{array}$ & $\begin{array}{l}\text { Size of } \\
\text { evacuating person }\end{array}$ & \multicolumn{2}{c}{$\begin{array}{l}\text { Evacuation Number of } \\
\text { fime }(\mathrm{min})\end{array}$} \\
dead person \\
\hline 1 & 517 & 5 & 8.63 & - \\
2 & 517 & 7 & 8.81 & - \\
3 & 788 & 5 & 18.17 & 1 \\
4 & 788 & 7 & 18.83 & 18 \\
\hline
\end{tabular}

Table 6: Shows the average temperature of the 1st floor

\begin{tabular}{lll}
\hline Case no. & Central area $\left({ }^{\circ} \mathrm{C}\right)$ & Front of right stairway $\left({ }^{\circ} \mathrm{C}\right)$ \\
\hline 1 & 21 & 21 \\
2 & 21 & 21 \\
3 & 21 & 21 \\
4 & 21 & 21 \\
\hline
\end{tabular}

Table 7: Shows the average temperature of the 2nd floor

\begin{tabular}{llll}
\hline Case no. & $\begin{array}{l}\text { Front of left } \\
\text { stairway }\left({ }^{\circ} \mathrm{C}\right)\end{array}$ & $\begin{array}{l}\text { Central } \\
\text { area }\left({ }^{\circ} \mathrm{C}\right)\end{array}$ & $\begin{array}{l}\text { Front of right } \\
\text { stairway }\left({ }^{\circ} \mathrm{C}\right)\end{array}$ \\
\hline 1 & 25 & 21 & 21 \\
2 & 26 & 21 & 21 \\
3 & 31 & 22 & 21 \\
4 & 34 & 23 & 22 \\
\hline
\end{tabular}

Table 8: Shows the average temperature of the 3rd floor

\begin{tabular}{llll}
\hline Case no. & $\begin{array}{l}\text { Front of left } \\
\text { stairway }\left({ }^{\circ} \mathrm{C}\right)\end{array}$ & $\begin{array}{l}\text { Central } \\
\text { area }\left({ }^{\circ} \mathrm{C}\right)\end{array}$ & $\begin{array}{l}\text { Front of right } \\
\text { stairway }\left({ }^{\circ} \mathrm{C}\right)\end{array}$ \\
\hline 1 & 29 & 30 & 108 \\
2 & 30 & 33 & 138 \\
3 & 41 & 42 & 191 \\
4 & 47 & 47 & 223 \\
\hline
\end{tabular}

Table 9: Shows the average temperature of the 4th floor

\begin{tabular}{llcc}
\hline Case no. & $\begin{array}{l}\text { Front of left } \\
\text { stairway }\left({ }^{\circ} \mathrm{C}\right)\end{array}$ & $\begin{array}{l}\text { Central } \\
\text { area }\left({ }^{\circ} \mathrm{C}\right)\end{array}$ & $\begin{array}{l}\text { Front of right } \\
\text { stairway }\left({ }^{\circ} \mathrm{C}\right)\end{array}$ \\
\hline 1 & 32 & 51 & 68 \\
2 & 34 & 58 & 80 \\
3 & 48 & 85 & 114 \\
4 & 56 & 101 & 133 \\
\hline
\end{tabular}

Table 10: Shows the $\mathrm{O}_{2}$ quantity of the 3rd floor $\mathrm{O}_{2}$ quantity of the 3rd floor (\%)

\begin{tabular}{lllllllll} 
Case no. & 1 & 2 & 3 & 4 & 5 & 6 & 7 & 8 \\
\hline 1 & 21 & 19 & 18 & 18 & 21 & 19 & 21 & 19 \\
2 & 21 & 19 & 11 & 13 & 21 & 19 & 21 & 18 \\
3 & 21 & 14 & 9 & 10 & 21 & 14 & 21 & 13 \\
4 & 21 & 14 & 11 & 11 & 21 & 13 & 21 & 13 \\
\hline
\end{tabular}

Table 11: Shows the CO quantity of the 3rd floor

\begin{tabular}{rllllllll}
\hline & \multicolumn{1}{l}{ CO quantity of the 3rd floor (PPM) } & & \\
Case no. & 1 & 2 & 3 & 4 & 5 & 6 & 7 & \multicolumn{1}{c}{8} \\
\hline 1 & 0.0 & 169 & 428 & 372 & 0.0 & 207 & 0.0 & 250 \\
2 & 0.0 & 252 & 1290 & 1020 & 0.0 & 258 & 0.0 & 429 \\
3 & 0.0 & 870 & 1570 & 1470 & 0.0 & 894 & 0.0 & 988 \\
4 & 0.0 & 984 & 1240 & 1260 & 0.0 & 1100 & 0.0 & 1080 \\
\hline
\end{tabular}

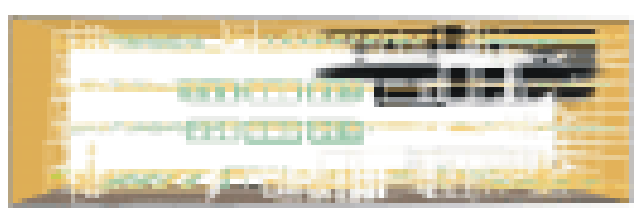

Fig. 5: Depicts the movement of smoke at $100 \mathrm{sec}$ of case 4

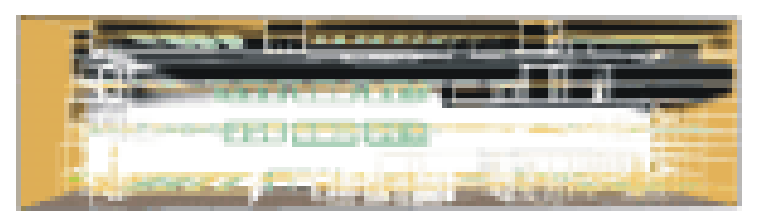

Fig. 6: Depicts the movement of smoke at $200 \mathrm{sec}$ of case 4 


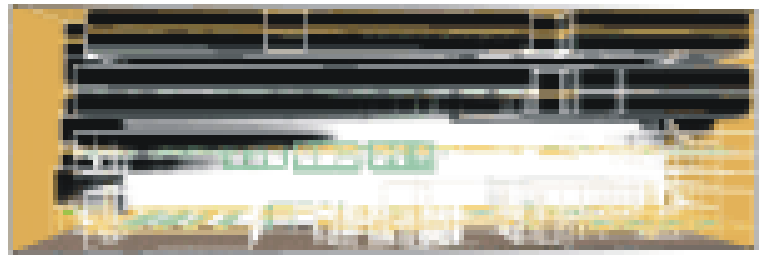

Fig. 7: Depicts the movement of smoke at $300 \mathrm{sec}$ of case 4

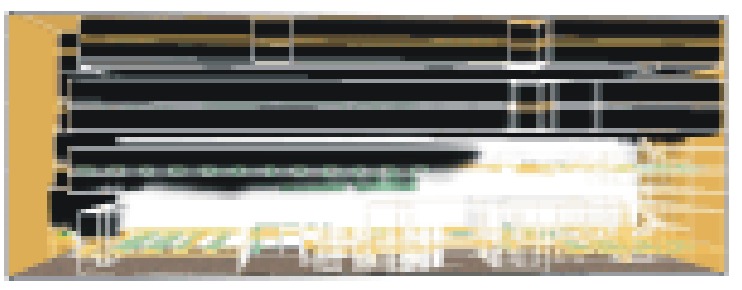

Fig. 8: Depicts the movement of smoke at $400 \mathrm{sec}$ of case 4

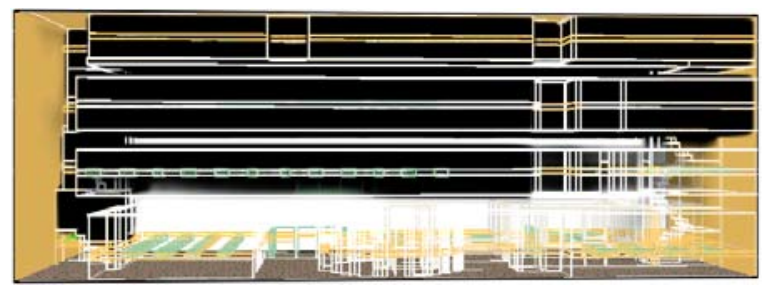

Fig. 9: Depicts the movement of smoke at $500 \mathrm{sec}$ of case 4

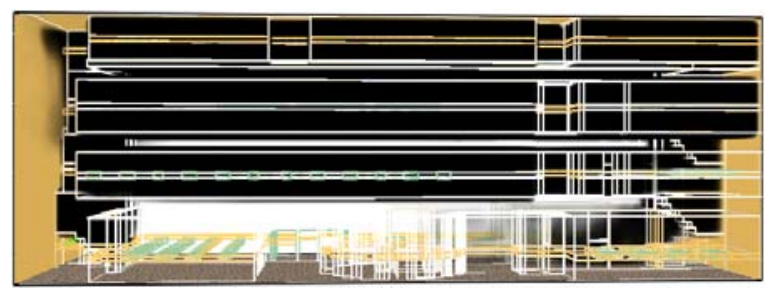

Fig. 10: Depicts the movement of smoke at $600 \mathrm{sec}$ of case 4

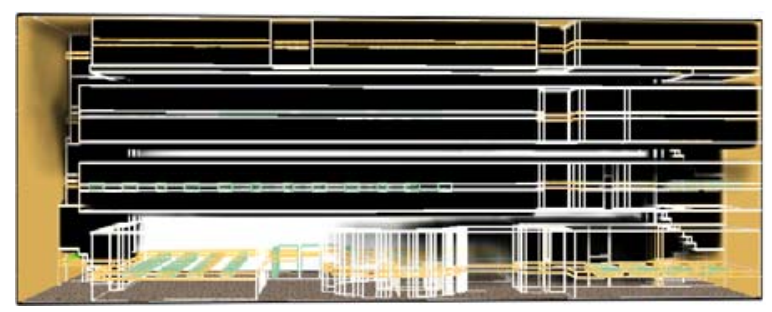

Fig. 11: Depicts the movement of smoke at $700 \mathrm{sec}$ of case 4

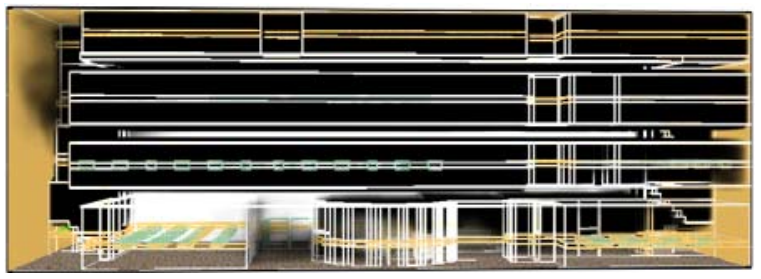

Fig. 12: Depicts the movement of smoke at $800 \mathrm{sec}$ of case 4

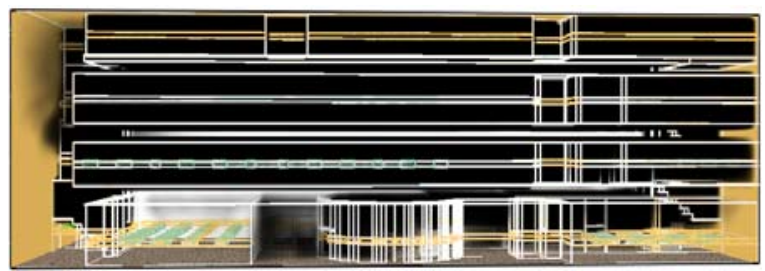

Fig. 13: Depicts the movement of smoke at $900 \mathrm{sec}$ of case 4

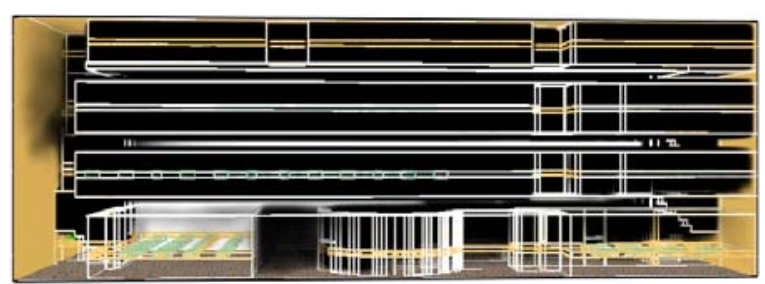

Fig. 14: Depicts the movement of smoke at $1000 \mathrm{sec}$ of case 4

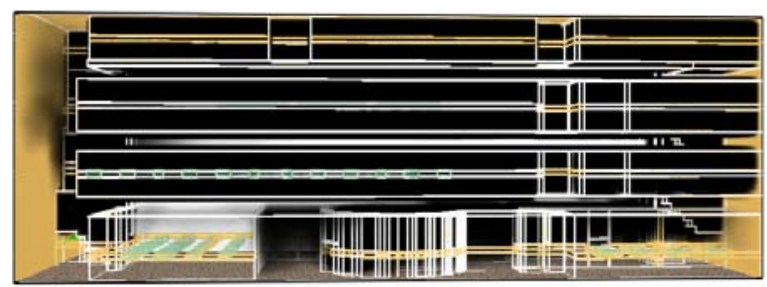

Fig. 15: Depicts the movement of smoke at $1100 \mathrm{sec}$ of case 4

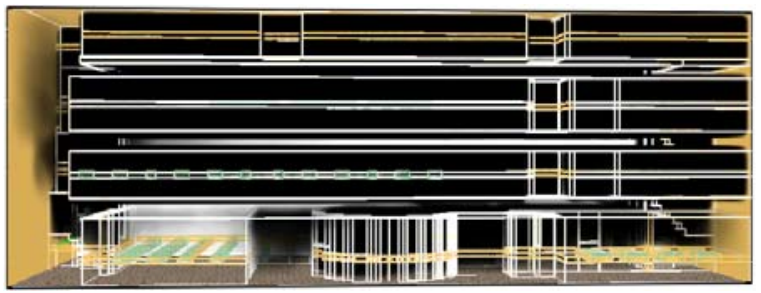

Fig. 16: Depicts the movement of smoke at $1200 \mathrm{sec}$ of case 4 


\section{DISCUSSION}

Most people choose the right stairway. Because the right stairway is larger than the left stairway. In case 3 and 4, people are dead in front of the right stairway of the 3rd floor where the temperature is the highest level. Average temperatures, while people died about $200^{\circ} \mathrm{C}$, which is higher than the people will be able to endure according with NFPA 130, the highest temperature that people can tolerate is $60^{\circ} \mathrm{C}$ for a few seconds. Indicators that show people were killed are Fractional Effective Dose (FED) is equal to 1, which is the result of adding together the percentage of $\mathrm{CO}, \mathrm{CO}_{2}$ and $\mathrm{O}_{2}$.

\section{CONCLUSION}

The location that found the dead people is at the $3^{\text {rd }}$ floor in front of the right stairway of the building. This location has the highest temperature compared with other floors because it closes to the source of a fire at $200^{\circ} \mathrm{C}$. Generally, the resistable temperature of human is $49^{\circ} \mathrm{C}$ with less than $6 \mathrm{~min}$. The percentage of $\mathrm{O}_{2}$ and $\mathrm{CO}$ quantity has the effect on the number of dead people, which is considered from the Fraction Effective Dose (or FED). The FED is a total of $\mathrm{O}_{2}, \mathrm{CO}$ and $\mathrm{CO}_{2}$ ratios, which equals to 1 and is a cause of human death. In addition, the study is also found that the increasing in the number of evacuating people and the toxic quantity has a direct effect on the evacuating people. The reason is high number of evacuating people that are waiting in a long period in front of stairway makes the increasing in the toxic quantity. So, the right stairway of the building has to be improved to increase the evacuation ability.

\section{REFERENCES}

Hu, L.H., R. Huo, W. Peng, W.K. Chow and R.X. Yang, 2006. On the maximum smoke temperature under the ceiling in tunnel fires. Tunnel. Underground Space Technol., 21: 650-655. DOI: 10.1016/j.tust.2005.10.003

Kwaire, A.A., H.M. Falih and H.A. Abdul Bari, 2009. Modeling of three phase system with NonNewtonian liquid using computational fluid dynamics model. Asian J. Ind. Eng., 1: 12-20.

Lin, C.J. and Y.K. Chuah, 2008. A study on long tunnel smoke extraction strategies by numerical simulation. Tunnel. Underground Space Technol., 23: 522-530. DOI: 10.1016/j.tust.2007.09.003

Ma, T.G. and J.G. Quintiere, 2003. Numerical simulation of axi-symmetric fire plumes: Accuracy and limitations. Fire Safety J., 38: 467-492. DOI: 10.1016/S0379-7112(02)00082-6

Majee, N.C. and A.B. Roy, 2010. Asymptotic behavior of an artificial neural network defined on multipartite directed graph. OnLine J. Biol. Sci., 10: 44-49. DOI: 10.3844/ojbsci.2010.44.49

Merchant, E.W., 1982. Modeling Fire Safety and Risk. In: Fire and Humans Behavior, Canter, D. (Ed.). Wiley, New York, pp: 293-314.

Merry, K., P. Bettinger and J. Hepinstall, 2009. Physical and biological responses of forests to tropical cyclones affecting the united states Atlantic ocean and gulf of Mexico coasts. Am. J. Environ. $\quad$ Sci., 5: 16-32. DOI: 10.3844/ajessp.2009.16.32

Momani, N.M., 2010. Business continuity planning: Are we prepared for future disasters. Am. J. Econ. Bus. Admin., 2: 272-279. DOI: 10.3844/ajebasp.2010.272.279

Mouilleau, Y. and A. Champassith, 2009. CFD simulations of atmospheric gas dispersion using the Fire Dynamics Simulator (FDS). J. Loss Prevention Process Indus., 22: 316-323. DOI: 10.1016/j.jlp.2008.11.009

National Fire Protection Association, 2000. NFPA 130, Standard for Fixed Guideway Transit and Passenger Rail Systems. 2000 Edn., National Fire Protection Association, Massachusetts.

NFPA 101, Life Safety Code, 2009. Edition National Fire Protection Association. 2009. National Fire Protection Association, Massachusetts.

NIST Special Publication 1018-5, 2010. Fire Dynamics Simulator (Version 5) Technical Reference Guide, National Institute of Standards and Technology. Maryland.

NIST Special Publication 1019-5, 2010. Fire Dynamics Simulation (Version 5) User's Guide, National Institute of Standards and Technology. Maryland.

Purser, D.A. 1995. Toxicity Assessment of Combustion Products. In: SFPE Handbook of Fire Protection Engineering, National Fire Protection Association, Massachusetts, pp: 2/28-2/146.

Qin, T.X., Y.C. Guo, C.K. Chan and W.Y. Lin, 2009. Numerical simulation of the spread of smoke in an atrium under fire scenario. Buil. Environ., 44: 5665. DOI: 10.1016/j.buildenv.2008.01.014

Roh, J.S., H.S. Ryou, W.H. Park and Y.J. Jang, 2009. CFD simulation and assessment of life safety in a subway train fire. Tunnel. Underground Space Technol., 24: 447-453. DOI: 10.1016/j.tust.2008.12.003 
Walter, W.Y. and K.C. Wan, 2005. A new method for selecting the design fire for safety provision. Fire Sci. Tech., 24: 133-149. DOI: 10.3210/fst.24.133

Xin, Y., J.P. Gore, K.B. McGrattan, R.G. Rehm and H.R. Baum, 2005. Fire dynamics simulation of a turbulent buoyant flame using a mixture-fractionbased combustion model. Combustion Flame, 141: 329-335.

DOI: 10.1016/j.combustflame.2004.07.001
Zahim, S.M., M. Norainon, J.M. Shawal and R.I.R.M. Taufika, 2009. Iterative numerical method of gate turn-off thyristor: Comparative study between $\mathrm{Si}$ and SiC. Am. J. Eng. Applied Sci., 2: 446-450. DOI: 10.3844/ajeassp.2009.446.450.

Zhang, X.G., Y.C. Guo, C.K. Chan and W.Y. Lin, 2007. Numerical simulations on fire spread and smoke movement in an underground car park. Buil. Environ., $\quad 42$ : $3466-3475 . \quad$ DOI: 10.1016/j.buildenv.2006.11.002 